\title{
\begin{tabular}{l|l} 
Mibraries & DSpace@MIT
\end{tabular}
}

\author{
MIT Open Access Articles
}

Reading Codicological Form in John Gower's Trentham Manuscript

The MIT Faculty has made this article openly available. Please share how this access benefits you. Your story matters.

Citation: Bahr, Arthur W. "Reading Codicological Form in John Gower's Trentham Manuscript." Studies in the Age of Chaucer 33.1 (2011): 219-262. CrossRef. Web.

As Published: http://dx.doi.org/10.1353/sac.2011.0025

Publisher: New Chaucer Society/Project MUSE

Persistent URL: http://hdl.handle.net/1721.1/77917

Version: Author's final manuscript: final author's manuscript post peer review, without publisher's formatting or copy editing

Terms of use: Creative Commons Attribution-Noncommercial-Share Alike 3.0 


\section{Reading Codicological Form in John Gower's Trentham Manuscript}

The broad agreement that has emerged in recent years on the relevance of paleographical and codicological evidence to literary interpretation in medieval studies has not yielded analogous consensus on best practices for such interdisciplinary endeavors, particularly when we begin thinking about whole manuscripts rather than individual texts. ${ }^{1}$ This dilemma stems largely from the "oscillation between the planned and the random" that the construction of medieval literary manuscripts so often seems to display. ${ }^{2}$ On the one hand, the fact that the great majority of them were commissioned for specific purposes or patrons makes it likely that some logic would animate their assemblage. Yet many factors combine to make such logics extremely difficult to unravel. Exemplar poverty rather than thematic connections may have led two texts to cohabit in a given manuscript; a short poem juxtaposed after a longer one may be there simply because it fits the space the scribe had left in the quire, and not because of the echoes of phrasing and image between

\footnotetext{
${ }^{1}$ Even the agreement on the relevance of codicology to literary study is hardly absolute. Perhaps the most insistently dissident view has come from the distinguished paleographers Richard H. and Mary A. Rouse, who argue that attempts to link the realms of codicological and literary analysis "harmfully blur the distinction between what an author composed, and the physical form in which that composition is presented in any manuscript. ... Literary creation and the physical layout of surviving manuscripts are not results of the same actions. ..." See their "Ordinatio and Compilatio Revisited," in Ad Litteram: Authoritative Texts and Their Medieval Readers, ed. Mark D. Jordan and Kent Emery, Jr. (Notre Dame, IN: University of
} Notre Dame Press, 1992), 113-34, quotation 124.

${ }^{2}$ The phrase is Ralph Hanna's, from "Miscellaneity and Vernacularity: Conditions of Literary Production in Late Medieval England," in The Whole Book: Cultural Perspectives on the Medieval Miscellany, ed. Stephen G. Nichols and Siegfried Wenzel (Ann Arbor, MI: University of Michigan Press, 1993), 37-51, quotation $37 \mathrm{f}$. 
the two. Literary scholars, trained to make arguments about thematic connections and formal echoes, are naturally inclined to see such ideational and aesthetic considerations at work rather than more mechanical ones, and this inescapable prejudice makes it both difficult and vital for us to grapple with questions like: when is it legitimate to propose literary interpretations of manuscripts' codicological features, or to use those features to support readings of texts they contain; and how can we know?

One possible if stringent condition would be the personal involvement of the author in the manuscript's construction. ${ }^{3}$ Besides valorizing authorial intention in a way that no longer commands universal support among literary scholars, however, this criterion severely limits the range of manuscripts available for analysis, excluding a great many-like the Trentham manuscript of John Gower that I will take up momentarily ${ }^{4}$ whose construction seems interpretably purposeful, but where the historical fact of that purpose is uncertain and irrecoverable. In this tension between interpretive impulse and factual unknowability, we can see brewing another version of the conflict between form and history that has been too readily accepted by some of the many recent studies

\footnotetext{
${ }^{3}$ This level of involvement satisfies even the Rouses, who acknowledge "exceptions and qualifications" to the starkly categorical position outlined above: "some authors," they admit, "did take a lively interest in how their texts would be presented physically. And a few [they specify Hoccleve and Christine de Pizan] . . . even took steps to ensure that the physical appearance of their texts conformed to their wishes.” “Ordinatio and Compilatio Revisited," 124. They imply that in such cases, the manuscript situation of texts becomes part of their authorially sanctioned meaning, and equally amenable to literary interpretation.

${ }^{4}$ The manuscript is now shelved as British Library Additional 59495, but that official name being both more unwieldy and less euphonious, I follow others in here continuing to refer to it as Trentham.
} 
appealing for renewed attention to questions of form or aesthetics. ${ }^{5}$ One of my main goals in this essay will be to suggest that this is a false dichotomy, ${ }^{6}$ and to propose a notion of codicological form as one way of bringing form and history into more fruitful collaboration. ${ }^{7}$ I take form here to mean both the structure or arrangement of parts (here the individual texts that make up the manuscript); and their rhetoric or "style," all the

${ }^{5}$ Marjorie Levinson's recent review article (“What Is New Formalism?”, PMLA 122 [2007]: 558-69) offers a survey of the many disparate studies and approaches that have self-consciously concerned themselves with form and aesthetics, even as it is skeptical of how coherent a movement or methodology these studies have produced. (Indeed, just what to call this movement or movements remains an open question.) To Levinson's fine bibliography I would add volume 104.1 (2008) of Representations, which appeared after her essay and is devoted to explorations of form, formalism, and aesthetics; and, for their particular value to medievalists, Peggy Knapp's Chaucerian Aesthetics (New York: Palgrave Macmillan, 2008); and volume 39.3 (2005) of The Chaucer Review, which is devoted to Chaucer and aesthetics.

${ }^{6}$ Many recent studies have lamented this opposition, but Samuel Otter's "An Aesthetic in All Things" (Representations 104 [2008]: 116-25) produces a particularly compelling reading of form with, rather than against, history. Taking up two sentences about rope from Moby Dick, he points out that the historical fact of where Manilla and hemp rope (the two varieties being discussed) were produced in the nineteenth century complicates the seemingly straightforward racial metaphor in the passage; historical context thus creates rather than deadens stereotypically "literary" forms of allusion and metaphorical play. (Otter's essay is also valuable for imposing some clarity on three terms that have frequently been conflated in recent discussions: form, formalism, and aesthetics.)

${ }^{7}$ For an eloquent recent argument along these lines, see Maura Nolan's "Lydgate's Worst Poem," in Lydgate Matters: Poetry and Material Culture in the Fifteenth Century, ed. Lisa H. Cooper and Andrea Denny-Brown (New York: Palgrave Macmillan, 2008), 71-87. She uses the codicological situation of Lydgate's Tretise for Lauandres" to argue for reading the poem, in one manuscript at least, as a metaphorically and aesthetically complex work, rather than the laughable doggerel it has usually been considered. 
minute details and indeterminacies that invite and reward close reading. ${ }^{8}$ Applying this second understanding of form to codicology may seem counterintuitive, but we will see that the disposition of texts in a manuscript can in fact be as richly productive of aesthetic and metaphorical meaning as "words in poetry," to quote Derek Pearsall's bracing defense of literary appreciation. ${ }^{9}$ In proposing an analogy between "words in poetry" and "texts in manuscripts," I am not claiming that manuscripts are functionally equivalent to poetry. Doubtless the great majority of medieval manuscripts do not offer "metaphorical potentialities" in their selection and arrangement of texts. But when we are faced with the appearance of interpretively meaningful design in a manuscript, we should be open to how that creates meaning not just in individual poems, but in the broader concatenation of their codicological form, even when the concrete impulses behind that form remain unknowable. Codicological form, I suggest, rewards reading as both history and art.

\footnotetext{
${ }^{8}$ On these understandings of form and the apparent tension between them (the one concerned with largescale structure, the other with fine-grained detail), see the incisive comments of Catherine Gallagher in "Formalism and Time," Modern Language Quarterly 60 (2000): 229-51, especially 230-32.

${ }^{9}$ Lamenting that the "propositional content" that has constituted the chief interest of many Chaucer critics is "only a part of what and how poems mean," he continues: "Poetry, as a form of 'literature,' exploits potentialities in language, especially metaphorical potentialities, that are not exploited by other forms of discourse. Words in poetry, in the way they are chosen and arranged, have a wider range of possible meanings than they have in ordinary discourse, and not in any way confined to denotation..." See his "Towards a Poetic of Chaucerian Narrative," in Drama, Narrative, and Poetry in the Canterbury Tales, ed. Wendy Harding (Toulouse: Presses Universitaires du Mirail, 2003), 99-112, quotation 99 f.
} 
The Trentham manuscript is an attractive test case for this proposition because it merits attention in other ways, too. ${ }^{10}$ Composed entirely of texts by Gower, it includes works from throughout the poet's career, in all three of his literary languages, among them the only surviving copy of both In Praise of Peace and the Cinkante Balades. Its opening texts, moreover, directly address a newly crowned Henry IV, while the remarkable symmetry of its arrangement of texts, and the internal connections between them, give the impression of purposive and quite sophisticated design. This strong appearance of design, coupled with Gower's well-known and much-discussed shift to the Lancastrian cause, encourages interpretation of the whole as celebrating Henry's coronation; and indeed, from as early as the seventeenth century the only real debate among commentators has been whether Trentham itself was given to Henry, or whether it was the plainer draft copy for a now-lost presentation manuscript. ${ }^{11}$ Yet no external

\footnotetext{
${ }^{10}$ This attention, sadly, it has not generally received, although Siân Echard has recently written a fine account of the manuscript's post-medieval transcription and editorial history in Printing the Middle Ages (Philadelphia: University of Pennsylvania Press, 2008), 97-125. She there identifies (124) one key aspect of modern editorial practice that has marginalized Trentham: our tendency to collect shorter texts on linguistic rather than codicological grounds. Trentham's texts are thus dispersed into three of the four volumes of G. C. Macaulay’s Complete Works of John Gower (Oxford: Clarendon Press, 1899-1902), and the fascinating multilingualism of the whole must be reassembled by the modern reader by recourse to Macaulay's textual notes and introductions (or, of course, by study of the original artifact).

${ }^{11}$ The first blank leaf of the manuscript contains a note in the hand of Sir Thomas Fairfax, its owner in the seventeenth century, identifying the compendium as "Sr. John Gower's learned Poems the same booke by himself presented to kinge Edward ye fourth at his Coronation," with "Edward" subsequently corrected to "Henry" and "or before" added above "att," after which the words "att" and "or" were struck through. G. C. Macaulay points out that Fairfax was unlikely to have trustworthy authority for his claim that Trentham
} 
historical record justifies this certainty, ${ }^{12}$ and on thematic grounds, too, we will see the manuscript's overall trajectory gradually shies away from its early texts' direct royal addresses and could thus be read as working at cross purposes with its generally accepted goal. The material state of the manuscript further complicates the situation, for though

itself was presented to Henry; he thinks it more likely "that this was not the actual presentation copy, but another written about the same time and left in the hands of the author," largely on the grounds of its not being ornate enough. See his Complete Works of John Gower, vol. 1, lxxix-lxxxiii for his entire description of the manuscript. John H. Fisher, in John Gower: Moral Philosopher and Friend of Chaucer (New York: New York University Press, 1964), argues by contrast that "both the script and initials appear to be up to the standard of the best Gower manuscripts" (72), but does not actually dispute Macaulay's conclusion. R. F. Yeager likewise concurs with Macaulay, noting that "the manuscript is plain, unlike most royal presentation copies." See further his “John Gower's French," in A Companion to Gower, ed. Siân Echard (Woodbridge: D.S. Brewer, 2004), 137-51 (quotation 145).

${ }^{12}$ The contrast with another poetic compilation that has been described as a royal presentation copy is instructive. Bibliothèque Nationale fr. 831 is a collection of Froissart works, arranged in roughly chronological order and including introductory and concluding rubrics that identify Froissart as having "made, versified, and ordered" ("fais, dittés et ordonnés") the poems it contains. Since Froissart claims in his Chronicles to have presented a compilation of his poetry to Richard II; the manuscript is known to have been in England by the early fifteenth century; and it omits poems included in a largely parallel collection, Bibl. Nat. fr. 830, that might have proven politically distasteful to England generally or Richard specifically, Sylvia Huot suggests that "it is possible" that MS 831 could be volume referred to by Froissart. She nevertheless acknowledges that even this preponderance of evidence - collectively far stronger than anything in Trentham - "does not prove [the point] conclusively." See her From Song to Book (Ithaca, NY: Cornell University Press, 1987), 238-41. This example suggests how much more evidence we might want before concluding definitively on the intended or actual audience of the Trentham manuscript. 
generally well preserved, Trentham has been damaged in two key places. ${ }^{13}$ The end of the dedication to the Cinkantes Balades and the first poem of the sequence proper have been mangled, leaving about one and a half stanzas of each illegible; and the loss of an entire page has deprived us of the end of "Ecce patet tensus" (if that poem is in fact incomplete), ${ }^{14}$ the first balade and a half of the subsequent Traitié, and whatever linking material might once have joined them. The evidence of the scribal hands is also ambiguous. With two exceptions, all of Trentham's texts were written by the Scribe 5, identified by Malcolm Parkes, who also worked extensively on a number of other Gower compilations. ${ }^{15}$ The exceptions are "Ecce patet tensus" and "Henrici quarti primus," which were copied by Parkes's Scribe 10, who wrote two of the final poems in Cotton Tiberius A.iv but otherwise appears in no other Gower manuscripts. ${ }^{16}$ Both scribes added various revisions and corrections, but Parkes suggests that Scribe 10 added his texts after Scribe 5 had finished his work. We therefore cannot prove that Gower, Scribe 5, or any other identifiable agent intended Trentham to have the codicological form that it does. The manuscript thus presents its modern readers with an interpretive quandary. Its suggestions of purpose are too numerous and fundamental to ignore, but they are

\footnotetext{
${ }^{13}$ Except where otherwise attributed, these comments are based on my time working with the manuscript in the British Library in the summer of 2008; I am extremely grateful to the staff there for their help.

${ }^{14}$ Macaulay argues that it is, on the basis of this missing page (Complete Works, vol. 1, lxxx), but this is impossible to know, since the poem is unique to Trentham and ends grammatically, if a bit abruptly.

${ }^{15}$ See Malcolm B. Parkes, "Patterns of Scribal Activity and Revisions of the Text in Early Copies of Works by John Gower," in New Science out of Old Books: Studies in Manuscripts and Early Printed Books in Honour of A.I. Doyle, ed. Richard Beadle and A.J. Piper (Aldershot, 1995), 81-121 (esp. 90 f.)

${ }^{16}$ Ibid., 94.
} 
sufficiently complicated by literary ambiguity and material uncertainty that we cannot extract from the manuscript a single goal, audience, or agent.

I believe this is less of a problem than it might seem at first. Ambiguity of purpose or meaning, after all, hardly disqualifies texts from literary analysis; quite the reverse. And Trentham's codicological indeterminacies can be read in aesthetic terms even if accidentally produced, for a range of recent works in medieval studies have demonstrated the potential of thus interpreting objects seemingly resistant to such readings. ${ }^{17}$ Intention is in any event hardly a readily knowable category, even (or especially) when openly declared. ${ }^{18}$ Maura Nolan has therefore argued that in contexts like these we should not insist upon provable authorial or scribal intention, but instead "locate intention in the manuscript, where it is lodged in the interstices of the various sequences of poems that structure it...."19 This gambit does not simply transfer the author-function intact to an inanimate object, for both the inherently collaborative nature

\footnotetext{
${ }^{17}$ Two provocative essays from Paul Strohm's excellent recent collection (Middle English: Oxford TwentyFirst Century Approaches to Literature [Oxford: Oxford University Press, 2007]) are relevant here. Christopher Cannon's "Form" (175-90) proposes that the apparent resistance of many Middle English texts to formal analysis in fact makes this type of inquiry more rather than less essential, and his analysis of Handlyng Synne bears out that point. Lisa H. Cooper's “The Poetics of Practicality" (491-505), meanwhile, takes the self-avowedly "impractical" (492) aim of finding a meaningful poetics in even the most apparently prosaic of places—instruction manuals for producing concrete objects like books or ointmentsand produces richly complex readings.

${ }^{18}$ On this notion as it relates to medieval studies particularly, see for example Paul Strohm's "What Can We Know about Chaucer That He Didn't Know about Himself?", in his Theory and the Premodern Text (Minneapolis: University of Minnesota Press, 2000), 165-81.

19 “Lydgate's Worst Poem," 80, emphasis hers.
} 
of manuscript production and the factual uncertainties surrounding nearly every medieval manuscript ensure that the intentions cited by Nolan cannot be totalizing or unitary; indeed, as she goes on to note, codicological form both inspires and anchors meanings "that seem, at first glance, to be unauthorized or illicit, and to exceed the brief of the manuscript or the words on the page." ${ }^{20}$ History of various sorts has a vital role to play here, both in grounding potentially fanciful interpretations and in preventing this approach as a whole from turning into a codicological kind of New Criticism, devoted to beautiful close readings of the interplay of texts in manuscripts without reference to the historical circumstances of either. ${ }^{21}$ The history that will most directly inform my analysis of Trentham is Gower's own authorial history, which the manuscript's texts revise and reimagine at several key points. My broader argument is not that literary ambiguities are metaphorically interchangeable with other kinds of unknowability. Rather

\footnotetext{
${ }^{20}$ Ibid., 82, emphasis mine. On the importance of collaborative models to understanding the literary nature of medieval manuscripts, see Deborah McGrady, Controlling Readers: Guillaume de Machaut and His Late Medieval Readers (Toronto: University of Toronto Press, 2006); and Elizabeth J. Bryan's Collaborative Meaning in Scribal Culture: The Otho Lazamon (Ann Arbor, MI: University of Michigan Press, 1999).

${ }^{21}$ Like Nolan, Samuel Otter emphasizes the role of history in helping us see the "excess" that is a key component of the literary: he insists we remain "alert to the humor, the excess, and the complexities of both history and text," and later, discussing Ishmael's parenthetical aside from which he draws his title, he argues that the parentheses themselves "point to the relationships between the words inside and outside of their borders and on and off the page," again drawing attention to "varieties of literary excess, in whose pursuit I have sought to articulate a literary historicism." "An Aesthetic in All Things," 121-23, emphasis mine. It is worth noting that in metaphorically reading various punctuation marks' physical appearance, Otter offers his own interpretation of codicological form.
} 
it is that choosing to read Trentham's codicological form as meaningful despite its uncertainties allows us fuller engagement with the aesthetics of its literary texts, and the complexity of their multiple histories.

Close examination of the Trentham manuscript's overarching structure will establish both its strong appearance of design and the interpretive problems that arise when we try to pin down that design's precise nature. The manuscript contains the following texts:

1) seven lines of Latin verse addressed to Henry IV ("Electus Christi pie Rex Henrice")

2) 385 lines of English decasyllabic rime royal (In Praise Of Peace)

3) Latin prose link identifying the preceding work as carmen de pacis commendacione, and naming Gower as author of both it and the following epistola

4) 56 lines of Latin verse ("Rex celi deus")

5) one three-stanza dedicatory balade in French addressing the king, followed by Latin (twelve lines of verse, two lines of prose) and a second, four-stanza French dedicatory balade, both of which address Henry by name

6) fifty-two French balades totaling 1390 lines, with French incipit and Latin explicit (the Cinkante Balades)

7) 36 lines of Latin verse ("Ecce patet tensus," possibly incomplete owing to loss of one folio) 
8) the Traitié pour essampler les amantz marietz, here missing the first balade and a half owing to the loss of one folio but in all other manuscripts consisting of eighteen balades totaling 385 lines of decasyllabic rime royal

9) seventeen lines of Latin verse on love and marriage, drawn from lines that follow the Traitie in all ten of its extant manuscripts

10) twelve lines of Latin verse referring to Henry IV ("Henrici quarti primus") The first point to emerge from this brief resume is the extent to which the manuscript concerns the newly crowned Henry IV, whom the opening Latin verses directly address. Of the three longest works, In Praise of Peace also addresses him by name, and the Cinkante Balades are dedicated to him. "Rex celi deus" is a prayer to God on Henry's behalf and fulsomely praises the monarch, who then recurs in the first line of the manuscript's final poem. Given their explicit links to Henry, the fact that In Praise of Peace and the Cinkante Balades are unique to Trentham heightens the sense that this particular object, or one modeled on it, was designed for him.

This impression of design is strengthened by the remarkable symmetry with which the manuscript's texts have been arranged, a pattern that this streamlined list of its contents will emphasize:
A) brief Latin verses addressing Henry
B) 385 lines of vernacular rime royal stanzas, followed by Latin matter (prose explicit and incipit to following text)
C) 56-line Latin poem
D) Cinkante Balades, preceded by dedicatory and introductory material in French and Latin; followed by Latin explicit 
C') 36-line Latin poem (possibly incomplete)

B') 385 lines of vernacular rime royal stanzas (assuming missing material identical to all other manuscript witnesses), followed by Latin matter (seventeen lines of verse)

\section{A') brief Latin verses referring to Henry}

The symmetry is not perfect (though the identical length of In Praise of Peace and the Traitié is remarkable), but it is marked enough to suggest definite effort. So too is the way the Latin is woven throughout the manuscript, framing it at the beginning and end (A and A') and recurring after each major vernacular work as a kind of literary palate cleanser ( $\mathrm{C}$ and $\mathrm{C}$ '). Four of the five main poems, in turn, are further linked by textual matter ranging from simple incipits and explicits to sets of dedicatory verses, ${ }^{22}$ indicating an attempt to unite the manuscript's disparate languages and genres into a coherent

\footnotetext{
${ }^{22}$ As pointed out above, the folio that contained the first balade and a half of the Traitié has been lost, so we cannot be certain that there was ever a link existed between it and the preceding "Ecce patet tensus," though the evidence of the rest of the texts in the manuscript would make it surprising if there wasn't. The Cinkante Balades are preceded by two dedicatory balades with Latin verses and prose in between; these verses are themselves a combination of the first eight lines of the "O recolende, bone, pie Rex Henrice" and the brief four-line "H. aquile pullus." The link between the Cinkante Balades and "Ecce patet tensus," by contrast, is a brief explicit: "Expliciunt carmina Iohannis Gower, que Gallice composita Balades dicuntur." In Praise of Peace, "Rex celi deus," the Latin prose that links the two poems, and the manuscript's opening “Electus Christi, pie Rex Henrie” are all included in Macaulay's second volume of Gower's English works in the order that they appear in Trentham. Similarly the Latin verses that connect the Traitie and "Henrici quarti primus" are printed immediately following the Traitié in his volume of Gower's French works. See Complete Works vol. 3, 481-94, and vol. 1, $391 \mathrm{f}$. These represent two of Macaulay's relatively rare nods to codicological rather than linguistic unity.
} 
whole. Given Gower's history as Lancastrian supporter, and Trentham's insistent address to Henry in its opening texts, we can imagine interpreting its multilingual codicological symmetry as an elaborate compliment to the new king: just as Trentham uses Gower's poetry to unite into a pleasing whole the multiple languages set loose upon the world by human pride at Babel, for example, so too will the manuscript's royal recipient prove able to reunite his fractious kingdom, undoing the political chaos that Gower so strongly associated with linguistic divisioun. ${ }^{23}$

Yet Trentham's codicological form resists such a tidy summary of its propositional content, for plenty of other texts and contexts in the manuscript work against a Henrician reading of both parts and whole. "Ecce patet tensus" takes blind Cupid to task for the destructive effects of love-Henry is not mentioned - and the Traitié likewise offers no explicit connection with the king. The Traitié's various exempla demonstrate a pointed interest in royal misbehavior that might suggest admonitory content for the newly crowned Henry, but this interpretation at first seems hard to square with the manuscript's earlier praise of him. We should note, too, that references to the king become thinner and more oblique as the manuscript progresses: its three longest texts go from embedding an address to Henry in the poem itself (In Praise

\footnotetext{
${ }^{23}$ On this connection see the chapter on Gower in Mary Catherine Davidson's Medievalism, Multilingualism, and Chaucer (New York: Palgrave Macmillan, 2009); Tim William Machan, "Medieval Multilingualism and Gower's Literary Practice," Studies in Philology 103 (2006): 1-25; Diane Watt, Amoral Gower (Minneapolis: University of Minnesota Press, 2003), 21-37 and especially 32-35; and Rita Copeland's discussion in Rhetoric, Hermeneutics, and Translation (Cambridge: Cambridge University Press, 1991), 213-220. As Machan puts it (2), "sociolinguistically, language change and variation originated because of human pride and in this sense testify, like all moral failures, to our fallen condition."
} 
of Peace), to sequestering this address outside the text proper in dedicatory matter

(Cinkante Balades), to finally just offering up historically distant royal figures for moral assessment (Traitié). The considerable length of the Cinkante Balades means, moreover, that nearly all of the numerous direct addresses to the king take place in the first quarter or so of the manuscript. When he recurs at the very end, in "Henrici quarti primus," it is only to measure time: "It was in the first year of the reign of King Henry IV" that Gower went blind, he tells us. ${ }^{24}$ Instead of the monarch that its early texts addressed, Trentham concludes by emphasizing the author who composed them all: "Henrici quarti primus" includes seven first-person personal pronouns and six first-person verbs in its just twelve lines, which offer an intimate farewell to writing; and the preceding Traitié ends with a dedication that rather grandiloquently puts Gower in conversation with the entire world rather than just his king. ${ }^{25}$ All these facts make it difficult to sustain fully Trentham's initial invitation to read its texts in Henrician terms.

We should not conclude, however, that because Trentham's texts cannot all be equally drafted into service as part of a celebratory volume for Henry, the earlier

\footnotetext{
${ }^{24}$ See R. F. Yeager's edition and translation in John Gower: The Minor Latin Works (Kalamazoo, MI: TEAMS and Medieval Institute Publications, 2005), where it is included as a unique version of "Quicquid homo scribat," the first line of the poem as it appears in Oxford, All Souls College MS 98.

25 “Al universiteé de tout le monde, / Johan Gower ceste Balade envoie . ..” (XVIII.22-23). My citations of both the Traitié and the Cinkante Balades are from R. F. Yeager's edition and translation, John Gower: The French Balades (Kalamazoo, MI: TEAMS and Medieval Institute Publications, 2009), which he was gracious enough to allow me to consult before it went to press. My translations tend closely to track his, but are my own throughout unless otherwise noted. I take universiteé as even more all-inclusive than Yeager's community, and so: "To the entirety of all the world / John Gower sends this balade."
} 
indications of purpose we have considered—its multiple addresses to him, symmetrical arrangement, and codicological threading—all add up to uninterpretable accidents. In fact the manuscript demonstrates a clear, consistent interest in kingship, including but not limited to Henry's, for the three major texts not addressed to him explicitly—"Rex celi deus," "Ecce patet tensus," and the Traitié-all concern royal behavior and misbehavior. "Rex celi deus" prays to the king of its opening words, God, on behalf of the king identified in its incipit as Henry, while its text draws on a section of Vox Clamantis that addressed yet another king, Henry's predecessor Richard II; "Ecce patet tensus" depicts Cupid as a crowned king (coronatus) defined by chaotic and destructive misrule $;{ }^{26}$ and the Traitié cites a host of misbehaving kings to insist on self-control in love. Underlying this pervasive focus on kingship is another suggestive, chiastic structure emphasized by Trentham's symmetrical codicological form: the poems that follow the central Cinkante Balades recall their structural counterparts from the first half of the manuscript, but in darker or more ambivalent terms. In Praise of Peace is largely laudatory, its hints of disquiet kept mostly below the surface, while its chiastic other, the Traitié, uses the same rime royal stanza to take a darker tone, emphasizing the dire consequences of royal malfeasance. The fulsome praise of King Henry contained in "Rex celi deus," meanwhile, contrasts sharply with the comprehensive denunciation of King Cupid's rule in its codicological mirror image, "Ecce patet tensus." Even the brief initial and concluding Latin verses suggest this pattern. The opening "Electus pie rex Henrice" implies that Henry has inspired the poetry that follows, a suggestion that the next three

\footnotetext{
${ }^{26}$ For the text and translation, see R. F. Yeager, The Minor Latin Works (Kalamazoo, MI: Medieval Institute Publications, 2005), $40 \mathrm{f}$. Cupid is described as ipse coronatus at line 13.
} 
texts confirm. In "Henrici quarti primus," by contrast, the first year of his reign also marks Gower's farewell to writing. At the beginning of Trentham, Henry inspires poetic production; by its conclusion, the first year of his reign marks its cessation.

My point here is that even before we engage closely with its various individual texts, the Trentham manuscript itself subtly suggests a wide range of designs but refuses to allow us to settle comfortably on any single one of them. By celebrating Henry in its first three main texts, it strongly suggests one kind of purpose; it later undercuts the impression of that specific design, even as its sophisticated codicological form continues strongly to support the impression of some sort of design(s). The manuscript thus plays with our expectations and perceptions, creating a shifting, complex relationship between content and form. In so doing it enables us to apprehend it as more than just the material medium of its texts, and in fact as an aesthetically compelling work in itself. The question then becomes how, in the absence of provable audience or agent, to ground our interpretations of it, and here I will have recourse to another "history" to complement that of Trentham's codicological form: Gower's authorial history, which the manuscript frequently evokes and rewrites. Specifically, I will argue that Trentham's first two texts, those that most explicitly celebrate Henry's accession, rewrite poems from earlier in Gower's career in ways that raise cautionary doubts about that accession. These doubts become most fully legible, however, only when reconsidered in the context of the manuscript as a whole, after a reading of "Ecce patet tensus" and the Traitié, which are far more obviously cautionary but also far less explicitly connected with Henry. The manuscript thus crafts (at least) two different meanings for its first two poems: the largely celebratory explicit content that they would have on a first reading, and the darker 
resonance they might acquire only gradually and retrospectively, in conjunction with other texts and other aspects of Gower's career.

Gower's revision and rededication of the Confessio Amantis to Henry, comes Derbiae, is only the most famous instance of the poet's lifelong penchant for rewriting earlier works. ${ }^{27}$ A subtler form of rewriting also characterizes In Praise of Peace and "Rex celi deus." Frank Grady has demonstrated that the first of these returns to and reverses the opposition between Solomon and Alexander found in Book VII, where Alexander was presented as a model of philosophically enlightened governance and Solomon condemned for lustful idolatry. ${ }^{28}$ In Praise of Peace, by contrast, distinguishes between Solomon, who "ches wisdom unto the governynge / Of goddis folk" and thereby "gat him pees" (31-32, 35), and Alexander, who is introduced in the next stanza with the adversative Bot (36) and achieves his mythic status by war and conquest. Grady argues

\footnotetext{
${ }^{27}$ For a revisionist argument concerning the standard “three recension” narrative of the Confessio's composition, see Wim Lindeboom, "Rethinking the Recensions of the Confessio Amantis," in Viator 40
} (2009): 319-48. For an acute (and slyly humorous) reading of how Gower manipulates and rewrites images of kings in boats in Vox Clamantis and Confessio Amantis, see Frank Grady, "Gower's Boat, Richard's Barge, and the True Story of the Confessio Amanatis: Text and Gloss," in Texas Studies in Language and Literature 44 (2002): 1-15. Other poets also inspired Gower to recast past works; on his use of cento, the originally classical practice of constructing a poem out of lines written by earlier famous poets, see Eve Salisbury, "Remembering Origins: Gower's Monstrous Body Poetic," in R.F. Yeager, ed., Re-Visioning Gower (Asheville, NC: Pegasus Press, 1998), 159-84; R. F. Yeager, John Gower's Poetic: The Search for a New Arion (Woodbridge, Suffolk: D.S. Brewer, 1990), 52-60; and Yeager, "Did Chaucer Write Cento?," in John Gower: Recent Readings, ed. R. F. Yeager (Kalamazoo, MI: Medieval Institute Publications, 1989), 113-32.

28 “The Lancastrian Gower and the Limits of Exemplarity,” Speculum 70 (1995): 552-75. 
that Gower steps back at the last moment, and rather than "condemning Alexander, choos[es] instead to indict the world in which he existed, as if it deserved to be subdued and conquered." 29 This stark reversal of the roles they played in Confessio (a poem also ultimately dedicated, of course, to Henry of Lancaster), however, forces the reader of Trentham to think long and hard about the ramifications not just of Gower's cautionary use of Alexander here, but of the fact that the hero of one poem could so abruptly become the villain of the other.

Indeed, Gower's suggestion that Alexander's pagan world deserved conquest, in contrast with the "pite and grace" that Christians deserve from their princes (52), somewhat exculpates Alexander but even more deeply condemns Henry, should he follow such an example in his own Christian era. The bot that opened the stanza introducing Alexander is the first word of the next two stanzas as well, grammatically establishing the adversative as a central thematic in the poem as a whole, by which any affirmative statement can be instantly qualified, withdrawn, rewritten. The stanzas following those that introduce Alexander offer a wealth of examples:

It sit hem [Christian princes] wel to do pite and grace;

Bot yit it mot be tempred in manere.

So mai a kyng of werre the viage

Ordeigne and take...

Bot other wise if god himsilve wolde ...

Pes is the beste above alle erthely thinges.

${ }^{29}$ Ibid., 563. 
Thus stant the lawe, that a worthi knight

Uppon his trouthe may go to the fight;

Bot if so were that he myghte chese,

Betre is the pees, of which may no man lese.

$$
(52-53,57-63,67-70)
$$

These passages all allude to the fact that political idealism is subject to revision by practical realities. Grady notes the adversatives that here enact that revision, but argues that Gower forestalls the "implicit and dangerous analogy between Macedonian conquest and Lancastrian usurpation ... by plunging ahead on the theme of peace" and delaying the next adversative bot for some ten stanzas, "after the poem has safely established some momentum away from the vortex of this stanza [lines 64-70]."30 Gower cannot, however, so readily elide the larger and more daunting reality that his early use of the word bot suggests: just as any clear-cut statement can be undone by a simple adversative construction, so too the contrasting examples of Solomon and Alexander in the Confessio and In Praise of Peace demonstrate that a ruler once held up as an ideal can be textually deposed by subsequent rewriting.

In this context, the simplistic "praise of peace" contained in the next stanzas (e.g., "The werre is modir of the wronges alle" [106]) cannot be taken at face value, because as we saw in the bot-infused passages cited above, Gower has begun the poem as a meditation on the tension between moral idealism and political reality, giving neither a chance to triumph completely; we can hear a similar bot lurking behind the clear-cut

${ }^{30}$ Ibid., 565. 
statements of lines 71-133, waiting to undo them. And sure enough, the word returns later to qualify similarly straightforward principles:

Aboute a kyng good counseil is to preise

Above alle other thinges most vailable;

Bot yit a kyng withinne himself schal peise,

And se the thinges that been resonable...

Ha, wel is him that schedde nevere blod,

Bot if it were in cause of rihtwisnesse.

$(141-44,148-49)$

Later in the poem the word clusters so thickly that it threatens to undermine the explicit meaning of the text, as in the following passage:

Bot if the men within himself be veine,

The substance of the pes may noght be trewe,

Bot every dai it chaungeth uppon newe.

Bot who that is of charite parfit....

The bot's of lines 313 and 315 enclose and thus highlight the pessimistic statement of line 314; and while line 316 attempts to start a new stanza with a contrast that leaves this pessimism behind, its initial bot connects it both to the preceding stanza and to that word's thematization of abrupt reversals and subtle qualifications of seemingly straightforward commonplaces about good governance. The cumulative effect of all this 
is that when bot shows up twice in close proximity to Henry near the end of the poem, ${ }^{31}$ it is tinged with the ambivalence it has acquired over the course of the work as a whole.

This ambivalence is hardly overpowering. Bot is a sufficiently common word that it would be easy to ignore hints of deeper significance in it; the reversal of the Alexander / Solomon dichotomy, while striking, relies for its effect on the reader's familiarity with the antecedent in Confessio Amantis; and both these elements could be easily drowned out by the generally laudatory tone of the whole, set by the introductory Latin verses and straightforwardly celebratory opening stanzas. The cautionary undertones of In Praise of Peace are sufficiently subtle that they require a substantial level of active apprehension from the reader. In this they begin the Trentham manuscript's gradual construction of ambivalent patterns whose initial outlines - a fraught conjunction, a rewritten comparison — seem significant, and potentially threatening, only in retrospect. Here those outlines, if we choose to perceive them, suggest a recognition that whatever our idealistic wishes, the possibility remains that Henry's reign will slide off in the other direction: not peace but war; not ancestry or acclamation or any of the various Lancastrian claims alluded to in the poem's opening stanzas, ${ }^{32}$ but conquest - like Alexander's - pure and simple.

\footnotetext{
31 "Bot evere y hope of King Henries grace / That he it is which schal the pes embrace" (272-73); "Noght only to my king of pes y write, / Bot to these othre princes cristne alle ..." (379-80).

${ }^{32}$ For an overview both of the various claims put forth by Lancastrians in favor of Henry's accession and of how those claims find expression in literary texts, including In Praise of Peace, see Paul Strohm, "Saving the Appearances: Chaucer's Purse and the Fabrication of the Lancastrian Claim," in Barbara Hanawalt, ed., Chaucer's England: Literature in its Historical Context (Minneapolis: University of Minnesota Press,
} 1992), 21-40. 
The role of "Rex celi deus" in this process of gradually ambivalent rewriting is suggested by the explicit and incipit that link it with In Praise of Peace:

Here ends the poem about the excellence of peace, which in praise and memory of the most serene prince of God, King Henry IV, his humble orator John Gower composed. And now follows an epistle, in which with the highest devotion the same John entreats for the health and well-being of his said lord. ${ }^{33}$

The incipit to "Rex celi deus" in other manuscripts fails to identify Gower as author, ${ }^{34}$ whereas Trentham not only does so, but also emphasizes the identity of the John who writes (idem Iohannes) and Henry being written of (dicti domini sui) in the two texts. These identifications of Gower and Henry, moreover, depend on the first sentence, the explicit to In Praise of Peace that initially identifies them. These two sentences thus present the two poems as parallel efforts, such that their strategic rewriting becomes parallel too. "Rex celi deus," moreover, suggests a significantly more threatening binary than the Solomon/Alexander one of In Praise of Peace: Henry/Richard. ${ }^{35}$ The technique

\footnotetext{
33 "Explicit carmen de pacis commendacione, quod ad laudem et memoriam serenissimi principis domini Regis Henrici quarti suus humilis orator Iohannes Gower composuit. Et nunc sequitur epistola, in qua idem Iohannes pro statu et salute dicti domini sui apud altissimum devocius exorat." See Macaulay, Complete Works, vol. 2, 492.

${ }^{34}$ Cf. the All Souls manuscript, which reads "Here follows a poem by which our magnificent King Henry, singled out by God and men with every blessing, will be glorified" ("Sequitur carmen unde magnificus rex noster Henricus prenotatus apud Deum et homines cum omni benediccione glorificetur”). See Yeager, John Gower: The Minor Latin Works, $42 \mathrm{f}$.

${ }^{35}$ For a fascinating exploration of how this binary works in the repeated letters, $\mathrm{R}$ and $\mathrm{H}$, by which the two kings are known at the end of the Cronica Tripertita, see Robert Epstein, "Literal Opposition: Deconstruction, History, and Lancaster," Texas Studies in Literature and Language 44 (2002): 16-33.
} 
is different, however, for "Rex celi deus" gains its initial force precisely by declining to rewrite: its first eight lines are exactly the same as those that open VI.xviii of the earliest version of Vox Clamantis, the one most kindly disposed to Richard. The praise of Henry in Trentham thus recalls the fact that Gower once prayed, for example, that "it be granted to you, $\mathrm{O}$ king [Richard], always to hold the honored scepter firmly in your hand during our lifetime," or that "He Who gave you [Richard] your first realms [should] give you assurance of your future realms" (VI.1175 f. and 1187). That these lines appear almost unchanged in "Rex celi deus" suggests the contingent nature of the poem's praise of Henry,${ }^{36}$ particularly since Gower expunged and substantially rewrote this entire chapter from subsequent versions of the Vox, replacing them with much sterner admonitions to wise rulership. What happened to Richard could, in theory, happen to Henry.

Indeed, the epistle in the Vox from which "Rex celi deus" derives is addressed to Richard not by name but merely as "our king now reigning at present" (VI.viii.headnote), and "Rex celi deus," too, nowhere explicitly names Henry as the king being praised; we have to read the incipit to discover his identity. This fact further emphasizes the importance of Trentham's codicological links between texts. More broadly, the text's refusal to name the king explicitly, and decision to recycle praise of an earlier, now deposed monarch collectively emphasize both the transience of royal power and the ultimate instability of subjects' loyalty. The revised Vox states explicitly that "if you turn yourself strictly to your own affairs, then the people which should be yours will turn itself away" (VI.1197 f.). Far from condemning such behavior as disloyal fickleness, however,

\footnotetext{
${ }^{36}$ VI.18.1159-98. R. F. Yeager makes a suggestion similar to my argument here in his John Gower: The Minor Latin Works, 72.
} 
Gower implies that kings who cannot maintain the people's loyalty have only themselves to blame, and by transferring praise of Richard to Henry, he suggests that similar shifts are possible in the future as well - but in that case Henry would be the dispossessed party. As with In Praise of Peace, this is a subtle form of ambivalence that relies on knowledge of the text being alluded to and its then addressee, so I do not claim that "Rex celi deus" demands or even encourages this interpretation on a first reading. It gains cumulative force by being juxtaposed with In Praise of Peace, however, and further linked to that poem by the explicit/incipit that we considered above.

The Cinkante Balades that follows "Rex celi deus" is Trentham's central and longest text, yet immediately offers interpretive challenges, not least because forme fixe love-poetry is a genre of highly conventional topics, themes, and images. Fortunately Trentham's first two texts' understated evocations of Gower's authorial past offer a key way of grappling with the Cinkante Balades, which likewise rewrite the poet's authorial history as he himself has twice represented it. As early as the Mirour de l'Omme, Gower describes such "fols ditz d'amours" as the product of a misspent youth:

Jadis trestout m'abandonoie

Au foldelit et veine joye,

Dont ma vesture desguisay

Et les fols ditz d'amours fesoie,

Dont en chantant je carolloie

Mais ore je m'aviseray

En tout cela je changeray,

Envers dieu je supplieray 
Q'il de sa grace me convoie;

Ma conscience accuseray,

Un autre chançon chanteray,

Que jadys chanter ne soloie. ${ }^{37}$

This passage precedes the life of the Virgin that concludes the Mirour, so it is possible to interpret the many future tense verbs as referring only to the current poem. But combined with Gower's later and far more famous leave-taking from love in the Confessio (VIII.3138-72), it suggests that whenever they were originally written, the Balades as presented in Trentham represent a return to the literary and personal past. In the dedication to the Cinkante Balades, moreover, Gower emphasizes the newness and nowness of this gesture. After two stanzas praising the king, he writes:

Vostre oratour et vostre humble vassal,

Vostre Gower, q'est trestout vos soubgitz,

Puisq'ore avetz receu le coronal,

Vous frai service autre que je ne fis,

Ore en balade, u sont les ditz floriz,

Ore en vertu, u l'alme ad son corage:

Q'en dieu se fie, il ad bel avantage. ${ }^{38}$

\footnotetext{
${ }^{37}$ MO, 27337-49. "Once I entirely abandoned myself to foolish pleasure and vain joy, with which I adorned my appearance, and I made foolish poems of love to which I danced while singing. But now I will take counsel and change in all this; I will pray to God that He send me his grace; I will rebuke my conscience and sing a different song, which I have not in the past tended to sing."

${ }^{38}$ Ded. Balade I.15-21: "He who prays for you and is your humble vassal, / Your Gower, who is entirely your subject, / Since now you have received the crown, / I do you a service different from what I have done
} 
The first two ore's suggest an equivalence between the newness of Henry's kingship and that of Gower's poetic effort. The allusion to present service recalls Gower's earlier dedication of the Confessio to Henry, so at its most literal, this anaphoric ore simply analogizes the difference between King Henry and Henry comes Derbiae, and the difference between the literary works addressed to each. But while it may be literally true that Gower has never before written love-poetry for Henry, line 18's insistence that the forthcoming offering marks a break with the past ignores the fact that within Gower's own authorial history, love-poetry is the very genre that the poet has twice foresworn. The Cinkante Balades is a return to the past that presents itself as wholly new.

This is significant because it means that each of Trentham's first three texts has an important antecedent in Gower's authorial history: reversed exempla (In Praise of Peace), readdressed political praise ("Rex celi deus"), or renewed generic activity (the love-poetry of the Cinkante Balades). Moreover, Gower draws attention to this contrast between past and present elsewhere in the dedicatory balades:

Noz coers dolentz par vous sont rejois;

Par vous, bons Roys, nous susmes enfranchis, Q'ainçois sanz cause fuismes en servage....

Ensi le bon amour q'estre soloit El temps jadis de nostre ancesserie, Ore entre nous recomencer om doit 
Sanz mal pensier d'ascune vileinie. ${ }^{39}$

The repeated re-words (rejois, recomencer) emphasize that Henry is merely and properly restoring the good things his subjects have recently (i.e., under Richard) been denied. This is, of course, a prudent rhetorical position to adopt, and inasmuch as Gower's choice of genre recalls his own earlier depictions of his authorial history, we can see the outlines of a still more elaborate compliment: that in addition to returning his kingdom to an idealized past of freedom and "bon amour," Henry's accession has reversed the inexorable process of age that left Gower an absurd senex amans at the end of the Confessio, and thus enabled the poet at the dawn of the fifteenth century to take up once more the poetry of his youth in order to "desporter vo noble Court roia[1]."40

Nor are these allusions to and revisions of Gower's authorial history the only connections among Trentham's first three texts, for the dedicatory material to the Balades creates others. Gower's characterization of himself as the king's oratour in the passage we considered earlier (Ded. Bal. I.15) echoes suus humilis orator, the term used for him in the explicit/incipit between In Praise of Peace and "Rex celi deus." Even Trentham's opening Latin verses are echoed by later works; their initial characterization of the king

\footnotetext{
${ }^{39}$ Ded. Bal I.5-6: “Our grieving hearts are rejoiced by you; / By you, good King, we are freed, / Who before, without cause, were in servitude," and Ded. Bal II.21-24: “And so we should begin again, between us, the good love that used to exist in the former time of our ancestors - without a wicked thought of any villainy."

${ }^{40}$ Ded. Bal. II.27: “To entertain your noble roya[1] Court.” Venus tells Gower after receiving his letter in the Confessio that he must "remembre wel hou thou art old" (VIII.2439). It is only her later production of a mirror, however, which leads to a devastatingly exhaustive anti-blason of the poet's decrepitude (VIII.2820-33), that finally convinces Gower to abandon the posture and the poetry of courtly love.
} 
as "pie Rex" is taken up repeatedly by "Rex celi deus," where the epithet describes Henry five times in the poem's fifty-five lines. ${ }^{41}$ These Latin poems are also thick with the $r e-$ verbs of renewal and rejoicing that we saw in the passages from the Cinkante Balades cited above. ${ }^{42}$ Collectively these instances draw attention to the role of "minor" introductory and dedicatory texts in reinforcing the larger works that they surround and contextualize, and thus further encourage reading Trentham as a meaningfully constructed object.

What remains is to consider how, as constructed to this point, Trentham associates the seemingly dissimilar themes it treats: of politics and a Henrician restoration in In Praise of Peace and "Rex celi deus," and of love and desport in the Cinkante Balades. The echoes of phrasing and vocabulary that we considered above are a generalized kind of invitation to connect these two realms, but the anaphoric passage that we have already briefly considered offers a more pointed one:

Puisq'ore avetz receu le coronal,

Vous frai service autre que je ne fis,

Ore en balade, u sont les ditz floriz,

Ore en vertu, u l'alme ad son corage:

Q'en dieu se fie, il ad bel avantage.

\footnotetext{
${ }^{41}$ Lines 10, 21, 33, 51, 55. By contrast, he is described as "rex . . . fortissime" (41) and plain "rex" (30) just once each, which makes "pie Rex" by far the poem's favorite term for Henry, whom as we saw above the poem never addresses by name.

${ }^{42}$ Two of the seven lines of "Electus Christi, pie Rex Henrice" end with re-verbs: restituisti (3) and renovata (5); such verbs occur six times in just the first twenty-eight lines of "Rex celi deus" $(13,15,18$, $19,22,28)$.
} 
O gentil Rois, ce que je vous escris

Ci ensuant ert de perfit langage,

Dont en latin ma sentence ai compris:

Q'en dieu se fie, il ad bel avantage. ${ }^{43}$

The third ore links Henry's coronation, Gower's offering of love-poetry, and a concern for virtue that echoes the themes of In Praise of Peace and "Rex celi deus." This connection then leads into the envoy, which draws attention to the multilingualism of the dedicatory material and thus encourages us to read the entirety of that material - French poems, Latin verses, and Latin prose - as a single authorial gesture (“ce que je vous escris . . en latin ma sentence ai compris"). This is significant because the intercalated Latin material is emphatically political, and thus connects the amatory Cinkante Balades that it introduces with the preceding poems. ${ }^{44}$ Like "Electus Christi, pie Rex Henrice" and "Rex celi deus," these lines address Henry as "pie Rex" (1); like In Praise of Peace, they urge him to seek peace ("pacem compone," 5). We see references to the deliverance from Egypt and the sacred anointing oil of St. Thomas Becket, and prayers drawn from

\footnotetext{
${ }^{43}$ Ded. Balade I.15-25: "He who prays for you and your humble vassal, / Your Gower, who is entirely your subject, / Since now you have received the crown, / I do you a service different from what I have done before, / Now in balade, where poetry's flower resides, / Now in virtue, where the soul has its heart: / Whoever trusts in God has the best of it. / Oh gentle king, this which I write for you - / What follows here uses polished language, / Whose message I have written in Latin: / Whoever trusts in God has the best of it."

${ }^{44}$ The Latin is an odd mixture: the first eight lines of "O recolende, bone, pie Rex Henrice," followed by the four-line "H. aquile pullus" and a two-sentence prayer, in prose, offering a further prayer for Henry's health and success. The whole is included in R. F. Yeager's John Gower: The French Balades, 56-59.
} 
the Psalms that the people will "live under the rule of reason," and Henry will "moderate the powers of the crown." 45

None of this Latin in the least suggests the elegant love-poetry that follows, yet it is not just present in the manuscript, but obtrusively so, abruptly changing the language, verse form, images, and tone of the first dedicatory balade, which has nevertheless not just alluded to this Latin but presented it as Gower's own speech. We then shift, equally abruptly, back to French balade form and the vocabulary of "bon amour" in the second dedicatory poem that follows. Like the Trentham manuscript as a whole, then, the codicological form of the Cinkante Balades and its dedication offers a strong initial impression of design while presenting discontinuities that make that design hard to pin down. Here, however, the lexicon of virtue shared by both courtly-love speech and political discourse offers an interpretively helpful tangent point. The Latin praised Henry, "than whom no one is more gracious" ("quo nunquam gracior ullus," 9), and the French likewise identifies God as having imbued "Henri le quarte ... de grace especial” (Ded. Bal. II.2-3). The Latin's general emphasis on moral and political rectitude, combined with this sort of direct echo, enables us to read the dedicatory balades' explicit and insistent focus on virtue — long lists open the first and close the second poems ${ }^{46}$ —as suggesting a greater relevance for the following Cinkante Balades than mere desport.

\footnotetext{
${ }^{45}$ These references are at lines 2, 11, 4 ("vivant sub racione"), and 5 ("vires moderare corone") respectively; the quotations are from the Vulgate Psalms, 88:23 and 40:3.

46 “Pité, prouesse, humblesse, honour roial” (Ded. Balade I.1: “Mercy, prowess, humility, regal honor"), and "Honour, valour, victoire et bon esploit, / Joie et saunté, puissance et seignurie" (Ded. Balade II.33-34: "Honor, valor, victory, and good success, / Joy and health, power and lordship").
} 
This is significant because we will see that even in the context of the poems' generic expectations of intense erotic lament over the instability of love and the sudden shifts of Fortune, the Cinkante Balades present striking discontinuities of tone, narrative, and persona. I suggested earlier that it is possible to read Gower's representation of his return to love-poetry as a complimentary gesture to Henry and the personally rejuvenating effects of the king's renovatio imperii. The discontinuities in the Cinkante Balades proper, however, suggest another possible interpretation. If we read these fissures in the context of the dedication's concern with virtue, its normally distinct courtly and political associations blurred by that material's juxtaposition of the two discourses, their effects are reminiscent of the ambivalent authorial revisions we saw earlier with In Praise of Peace and "Rex celi deus"; that is, they subtly call into doubt the most purely celebratory attitude toward Henry's accession. As with Trentham's first two texts, there are plenty of reasons not to take up this darker interpretation: here, the conventionality of the genre and subject matter, which makes the interpretation of any larger significance, including the political, difficult to substantiate. My argument therefore is not that this is the only or necessarily best way, then or now, of reading the Cinkante Balaades themselves. Rather it is that Trentham's codicological form, its juxtaposition of poems and intervening material, and the echoes among them, is gradually offering an alternate, more cautionary way of understanding poems of both political praise and courtly desport.

I have space here to discuss only a few of the many delights and complexities offered by the Cinkante Balades, but even this truncated analysis requires a brief resume 
of the narrative arc that the sequence suggests. ${ }^{47}$ The male lover first laments his lady's inaccessibility, then attacks the scandal-makers who are damaging her reputation. He suggests that he will absent himself from her in order to preserve her honor and eventually does so, but then reproaches her for infidelity. She makes the same charge against him, but they are reconciled at the end of the sequence, which concludes with generalized thoughts on love and an address to the Virgin. Marked silences and discontinuities characterize this meta-narrative, however, the most striking of which is the shift in the lady's tone between Balades XLIII and XLIIII: the first of these concludes a set of three poems excoriating the lover's faithlessness, which she denounces as worse even than Jason's to Medea or Aeneas's to Dido. Yet the very next poem, also written in a female voice, praises him (or some male figure, at least) as "vailant, courtois, gentil et renomée / Loyal, verrai, certain de vo promesse." ${ }^{, 4}$ The change is sufficiently abrupt as to prompt wry, antifeminist commentary by G. C. Macaulay; R. F. Yeager suggests that a second, worthier lover has here taken the place of the first, but even if he is correct it remains a remarkably sudden shift. ${ }^{49}$

\footnotetext{
${ }^{47}$ R. F. Yeager has argued that Cinkante Balades have "a narrative unity, even a chronology, traceable through references to feast days and seasonal changes over the course of two or three years." See his "John Gower's French," 146. I find this meta-narrative both less consistently apparent and less coherent than does Yeager, but he is nevertheless right to emphasize its general contours.

${ }^{48}$ Balade XLIIII.1-2: "valiant, courteous, honorable and renowned, / Loyal, true, unwavering in your promise."

${ }^{49}$ Macaulay writes (Complete Works, vol. 1, lxvii) that once "the lady has her say . . . in accordance with the prerogative of her sex her moods vary with startling abruptness." Yeager makes his suggestion that there are two different lovers in John Gower: The French Balades, 49.
} 
How significant we judge this and other comparable discontinuities to be to the Henrician context that Trentham's opening texts have established will depend largely on how inclined we are to read the Cinkante Balades' representations of erotic virtue and constancy, deceit and treachery, in social or political terms. The text's only substantive codicological feature, which occurs early in the sequence, encourages us to ponder precisely this issue of the balades' deeper significance; two marginal glosses to Balades V and VI, respectively, read:

Les balades d'amont jesques enci sont fait especialement pour ceaux q'attendont lours amours par droite mariage.

Les balades d'ici jesqes au fin du livere sont universeles a tout le monde, selonc les propretés et les condicions des Amantz, qui sont diversement travailez en la fortune d'amour. ${ }^{50}$

Written in the same hand and with the same decoration as the balades themselves, the manuscript presents these glosses as integral to the poems they comment on. ${ }^{51}$ What they

\footnotetext{
50 "The balades from the beginning up to this point are made especially for those who wait on their loves in expectation of rightful marriage; the balades from here until the end of the book are universal, for everyone, according to the properties and conditions of Lovers who are diversely suffering the fortunes of Love." Yeager, John Gower: The French Balades, 134.

${ }^{51}$ The initial letter of the first margin note is gold, that of the second blue; this is the same pattern that predominates for the balades, all of which have an initial gold letter that usually (though not always, e.g. Balades XII and XXI) alternates with blue. On the importance of marginal glosses to Gower's work, and the Confessio in particular, see two articles by Siân Echard, “Gower's ‘bokes of Latin’: Language, Politics, and Poetry," Studies in the Age of Chaucer 25 (2003): 123-156; and "With Carmen's Help: Latin Authorities in the Confessio Amantis," Studies in Philology 95 (1998): 1-40; Ardis Butterfield,
} 
suggest, however, is distinctly odd. Only the first six poems, ${ }^{52}$ we are told, celebrate the that love which looks forward to marriage for its ultimate fulfillment; the remaining, far greater number address the many vicissitudes endured by those under la fortune d'amour. This trajectory-away from the legally permanent and divinely sanctioned love of marriage and into the Fortune-tossed seas of courtly wooing-contrasts sharply with the emphasis on stability, law, and virtue that we saw in the dedicatory material preceding the Cinkante Balades. It also runs counter to the trajectory of the manuscript as a whole, in which the courtly wooing of the Cinkante Balades is followed by the Traitié's defense of precisely the marital love that the Balades begin by briefly exploring, then cast aside. Of course, for this very reason it is possible to read that pairing as rationalizing and minimizing the disjunction provided by these two margin notes. But in the course of reading the Balades sequentially_-which their meta-narrative and their numbering in the manuscript encourage us to do-we experience the strangeness of a movement from marriage to courtly love.

Still more important, the reference to "droite mariage" grafts onto the first six balades a significance that they themselves nowhere make explicit or even particularly suggest. To be sure, in them the narrator promises his lady constancy and loyal love, which can in theory be taken as describing the permanent and holy bonds of marriage. But these terms are equally if not more characteristic of courtly-love discourse, and the

\footnotetext{
"Articulating the Author: Gower and the French Vernacular Codex," Yearbook of English Studies 33 (2003): 80-96; and Derek Pearsall, Gower's Latin in the Confessio Amantis," in Latin and Vernacular: Studies in Late-Medieval Texts and Manuscripts, ed. A.J. Minnis (Cambridge, N.H.: D.S. Brewer, 1989), $13-25$.

${ }^{52}$ The manuscript marks two adjacent Balades IV, so "Balade V" is actually the sixth in the sequence.
} 
first six poems also feature plenty of the pain-as-sweetness/sweetness-as-pain language that typifies such forme fixe expression and emphatically resists association with marriage:

D'ardant desire celle amorouse peigne

Mellé d'espoir me fait languir en joie;

Dont par dolçour sovent jeo me compleigne

Pour vous, ma dame, ensi com jeo soloie. ${ }^{53}$

Although this poem's refrain, "en attendant que jeo me reconforte," does pick up the lexicon of waiting from the first marginal gloss,${ }^{54}$ the vocabulary of the poem as a whole is such that only the most stubbornly ascetic reader would conclude that it is marriage for which the narrator is burning. The codicological form of the Cinkante Balades' opening, then, claims explicitly that very different interpretive contexts apply to these poems that look initially like straightforward representatives of their genre.

The second marginal gloss attempts to shut down this disconnect between apparent and deeper significance by reassuring us that the remaining, substantial majority of the balades are, in fact, just what they appear: poems about the travails of lovers and the fortunes of love. But the first gloss's introduction of extra-textual meaning is not so easily forgotten, since the supposed "marriage-balades" do not sound markedly different from those that follow. The effect of these glosses, I think, is to make us read the

\footnotetext{
${ }^{53}$ Bal. III.1-4: "This loving punishment of burning desire / Mingled with hope sickens me with joy: / Thus from sweetness often I complain / On your account, my lady - just so am I accustomed."

54 "Awaiting the time when I shall be comforted." Cf. the vocabulary of the first marginal gloss: "Les balades d'amont jesques enci sont fait especialement pour ceaux q'attendont lours amours par droite mariage," emphasis mine.
} 
Cinkante Balades as a whole more actively and more skeptically than the conventionality of their theme and expression might otherwise encourage. After all, if we are told that the opening poems of courtly desport actually signify something quite different, yet they seem broadly similar to those the manuscript insists are, in fact, just what they appear, then the arbitrariness of the distinction between them, and the initial encouragement to read for more than outward content, is likely to make us suspect the later poems, too, of containing some other or deeper meaning. In this spirit I read three of the most arresting moments in the sequence: the reappearance of one line from the dedicatory balades as the refrain to Balade XXI; the bizarre about-face of the lady toward her courtly lover alluded to earlier; and the concluding poems' attempts to define love, which raise again the glosses' contrast of "amours par droite mariage" and "la fortune d'amour."

But first, another instance of Gower's penchant for self-echoing: "sanz mal pens(i)er d'ascune vileinie" is both the refrain of Balade XXI and the twenty-fourth line of the second dedicatory balade. ${ }^{55}$ Gower's lover-persona is thus making the same address to his courtly lady that earlier, as poet, he made to his sovereign. In itself, the

\footnotetext{
${ }^{55}$ Ded. Bal. II.24 and Bal. XXI.refrain: "Without a wicked thought of any villainy." Yeager adds variation to the refrain in his translation by rendering vileinie variously as vulgarity, wickedness, deceit, and degradation, but the word remains the same throughout in the original (as of course it must, being part of a refrain). He also translates penser in Balade XXI as a noun ("without wicked thought of any vileinie"), and pensier in the dedicatory poem as a verb ("without thinking vileinie of any"). But pensier can just as easily be a noun (the orthographical difference between penser and pensier is not lexically significant), and it works better understood as such. For one thing this allows ascune to be an adjective modifying vileinie (as in Balade XXI), instead of a substantive that vileinie must look backward to - a considerably more awkward option. It is also thoroughly typical of Gower's career-long penchant for strategic revising and self-echoing, which we have already seen Trentham exploit in its first two texts.
} 
echo is not so surprising, since as we have seen the discourses of politics and courtly love share a lexicon of virtue (e.g., mal pensier, vileinie), but it does invite us to link the Balades themselves and their dedication, whose French-Latin-French structure conjoined political with amatory discourse, and which also linked the Cinkante Balades to the explicitly political In Praise of Peace and "Rex celi deus." If we take up this invitation to look outward for the Balades' significance, an invitation first made by the marginal glosses we just considered, then we find other similarities between the dedication and Balade XXI, as this comparison suggests:

Vostre oratour et vostre humble vassal, Vostre Gower, q'est trestout vos soubgitz,

Puisq'ore avetz receu le coronal,

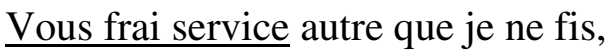

Ore en balade, u sont les ditz floriz,

Ore en vertu, u l'alme ad son corage:

Q'en dieu se fie, il ad bel avantage.

\section{Au solail, qe les herbes eslumine}

Et fait florir, jeo fai comparisoun

De celle q'ad dessoutz sa discipline Mon coer, mon corps, mes sens, et ma resoun

Par fin amour trestout a sa bandoun:

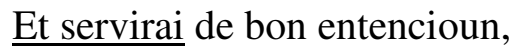
Sanz mal penser d'ascune vileinie. ${ }^{56}$

\footnotetext{
${ }^{56}$ Ded. Bal. I.15-21: "He who prays for you and is your humble vassal, / Your Gower, who is entirely your subject, / Since now you have received the crown, / I do you a service different from what I have done before, / Now in balade, where poetry's flower resides, / Now in virtue, where the soul has its heart: / Whoever trusts in God has the best of it." Bal. XXI.1-7: "To the sunshine that shines on the plants / And makes them flower, I compare / The one who has under her control / My heart, my body, my sense and my reason. / Because of the pure love entirely in her power -- / By that I shall live a joyful life. / And serve with good intention, / Without bad thought of any vulgarity."
} 
These and other, comparable similarities of phrasing and image that I could quote are sufficiently conventional that individually, they do not support much interpretive weight. Collectively, however, and in the context of the repeated "Sanz mal penser" line;

Trentham's insistent focus on politics generally and Henry specifically to this point; and the marginal glosses' initial invitation to read the balades in terms of other, essentially extra-textual interpretive programs, they suggest that the "bon amour" promised by the Cinkante Balades in some way reflects the political harmony that Lancastrian partisans hoped would result from Henry's accession.

Balade XXI particularly engages the reader's attention, moreover, because it reverses with striking suddenness the images and tones of the preceding Balade XX. That poem laments Fortune's unceasing hostility to the narrator, which he claims belies the adage that Fortune's wheel is always turning (XX.1-4). This perverse constancy is in conflict with the natural processes of change he observes elsewhere:

Apres la guerre om voit venir la pes, Apres l'ivern est l'estée beal flori, Mais mon estat ne voi changer jammes. ${ }^{57}$

This image of flowers following winter looks forward to the opening lines of the next balade, quoted earlier, where the narrator's constant torment has abruptly eased. The parallel, juxtaposed war-peace/winter-summer comparisons, meanwhile, further suggest a political resonance for these amatory poems, since both In Praise of Peace and the Latin

\footnotetext{
${ }^{57}$ Bal. XX.9-11: "After war one sees peace arrive, / After winter the beautiful foliage of spring; / But never do I see my situation change."
} 
dedication to the Cinkante Balades exhorted Henry to choose peace rather than war; and this context is sharpened by Balade XX's references to figures from the Trojan War. ${ }^{58}$ This conflict conjoined the political and the amatory not just in the celebrated judgment and abduction that precipitated it, but also in its aftermath (Agamemnon murdered by Clytemnestra), and in the way that Troilus's erotic fortune and ultimate fall paralleled those of his city. This is a theme with which Gower was intimately familiar, and not just as co-dedicatee of Chaucer's Troilus and Criseyde; he had earlier used London's associations with Troy in Vox Clamantis to inveigh against the rebels of the 1381 Rising and, with increasing harshness, Richard II as well. ${ }^{59}$ As we have seen, Gower's use of material from the Vox for Trentham's "Rex celi deus" implied that similar rewritings could occur to Henry, and Balade XX's Trojan references likewise allude to sudden and unforeseen reversals, though here in the realm of love: Fortune saw to Diomedes' happiness by changing Criseyde's affections (XX.19-21), for example, and though Gower does not allude to it here, we know what sort of welcome Agamemnon was to receive from Clytemnestra upon returning home from Troy. (If by chance we are ignorant of that episode, we will be educated by Balade VI of the Traitie at the end of Trentham....)

To this point the Cinkante Balades have given only brief hints of the metanarrative that makes the sequence more than a loosely juxtaposed set of forme-fixe lyrics, which minimizes the importance of psychological plausibility as a way of accounting for

\footnotetext{
${ }^{58}$ See Bal. XX.17-24, where Diomedes, Agamemnon, Troilus, and Calchas are all referenced.

${ }^{59}$ On Gower's use of Troy in Vox Clamantis (and indeed throughout his career), see Sylvia Federico, New Troy: Fantasies of Empire in the Late Middle Ages (Minneapolis: University of Minnesota Press, 2003), 128.
} 
the narrator's sudden shift from abject despair to reverent joy in Balades XX-XXI. But this larger issue of abrupt shifts in tone, and what if anything they suggest, returns dramatically when the lovers respond to one another in Balades XL-XLVI, by which time the initially fitful meta-narrative has been much more firmly established. The preceding Balade XXXIX is one of the most ecstatic in the set: the envoy concludes by sending many thousands of greetings ("Mil et Mil et Mil et Mil salutz," XXXIX.27) to one the lover hails as full of goodness (XXXIX.3). In the next poem, however, he abruptly accuses his lady of inconstancy, calling her a Helen to his forsaken Menelaus (XL.5 f.). This prompts a response of three increasingly furious balades (XLI-XLIII), in which she lobs back both the charge of faithlessness and the classical references: the lover is "au matin un et autre au soir" ("one person in the morning and another at night," XLI.25); a serial traitor of women (XLII.5) worse even than Jason or Aeneas (XLIII.15); and a lecher who beds his victims with greater haste than Hector displayed in arming himself at Troy (XLIII.9-11). And yet Balade XLIV, also in the lady's voice, fulsomely praises the lover with long lists of his virtues and the refrain that "au tiel ami jeo vuil bien estre amie. ${ }^{, 60}$

What on earth has happened? Even if the lover who graciously answers her in Balade XLV, and whose love she happily accepts in Balade XLVI, is as Yeager suggests a different person from the lover of Balades I-XL, the effect is exceptionally disorienting, and while Yeager's proposition of a love triangle may restore some semblance of psychological plausibility, it does so at the expense of narrative coherence,

\footnotetext{
60 "To such a friend/beloved I greatly wish to be a friend/beloved."
} 
for there have been only brief and tiny hints of a third party. ${ }^{61}$ In any event, no

interpretation can remove either the initial, highly destabilizing effect of the multiple

quick shifts in tone or the suspicion that something more is at issue than a lover's quarrel.

The allusions to Paris and Helen, Menelaus and Hector, return us to the Trojan context initiated in Balade XX and to that conflict's melding of the political and the erotic. The lady's most elaborate classical reference is also the most striking:

Unqes Ector, q’ama Pantasilée,

En tiele haste a Troie ne s'armoit,

Qe tu tout nud n'es deinz le lit couché. ... ${ }^{62}$

The counter-intuitive nature of this comparison-Hector's presumably laudable eagerness to defend Troy is similar to but exceeded by the lover's despicably quickacting lust—emphasizes by its strangeness the link between erotic vice and a great city's ultimate downfall, and, by extension, the vocabulary of love and politics.

Balade XLVI suggests a context for interpreting both these wild shifts in tone and the Trojan references that underlie them. Its opening stanza reads:

\footnotetext{
${ }^{61}$ The only evidence I could find is in the lover's repeated assertion in Balade XL that the lady has responded to another lover's suit: she has taken a Paris and abandoned his Menelaus (5 f.), and her "affection is not solely to one alone, / But rather to two" (21 f.). We could interpret this third figure as the lover she addresses in Balade XLIIII, and who responds in the following poem. It is a slight indication, however, and must be balanced against the lady's denials and counter-accusations, which are far more passionate than the lover's initial complaint.

${ }^{62}$ Bal. XLIII.9-11: "Never did Hector, whom Penthesilea loved, / Arm himself in such haste at Troy, / As you fully naked have lain down in bed. ..." The reference to Penthesilea also suggests the connection between love and battle: she is the queen of the Amazons who for love of Hector fights on the Trojan side, only to be slain by the son of Achilles. Gower tells her story in Confessio Amantis IV.2135-82.
} 
En resemblance d'aigle, qui surmonte

Toute autre oisel pour voler au dessure,

Tresdouls amis, vostre amour tant amonte

Sur toutz amantz, par quoi jeo vous assure

De bien amer, sauf toutdis la mesure

De mon honour, le quell jeo guarderai:

Si parler n'ose, ades jeo penserai. ${ }^{63}$

This is the final poem in the Cinkante Balades' narrative sequence-Balades XLVII-L offer general thoughts on love, and Balade LI is a concluding address to the Virgin—so its opening image of a soaring, noble eagle deserves special consideration, particularly since it echoes the four-line poem "H. aquile pullus," which concludes the poetic part of the Latin dedication to the Cinkante Balades and is included in a number of other Gower manuscripts as a self-standing poem:

H. son of the eagle, than whom no one is ever more graceful,

Has broken his enemies, and subjugated tyrannical necks.

H. the eagle has captured the oil, by which he has received the rule of the realm; Thus the new stock returns, anointed and joined to the old stem. ${ }^{64}$

\footnotetext{
${ }^{63}$ Bal. XLVI.1-7: "Just like the eagle, which surpasses / All other birds for flying up above, / Very sweet friend, your love ascends so / Above all lovers, for which I assure you / Of true love, saving always the measure / Of my honor, which I shall protect: / If I dare not speak, I shall think unceasingly."

${ }^{64}$ See Yeager, John Gower: The Minor Latin Works, $46 \mathrm{f}$. In addition to Trentham, the poem survives in five other manuscripts; in three of these, it follows the Cronica Tripertita that narrates the downfall of Richard II. Yeager writes further (78): 'the reference is to the 'Prophecy of the Eagle,' a thirteenth-century offshoot of the Merlin prophecies ... which among Lancastrian supporters associated Henry IV with an
} 
Prompted by this imagistic echo to look back to the dedication, we find further connections: the lady repeatedly praises this lover's prouesce $(9)$, valour $(11,23)$, and honour $(12,22)$ - all virtues attributed to Henry by the dedicatory balades that frame the Latin verses cited above. ${ }^{65}$

What are we to do, interpretively, with the abrupt tonal shifts, narrative discontinuities, and outward-looking allusions and references displayed by this sequence of poems? By this point, we have received a wide range of invitations from both the Cinkante Balades and the manuscript as a whole to read them as more than merely conventional reverses. The narrative sequence ends with the joy and devotion expressed in Balades XLIIII-XLVI, and given the last poem's reference to the lover as a soaring eagle, we might interpret this happy ending as an optimistic comment on the prospects for "bon amour," and the hosts of virtues associated with it by the dedication, under the ascendance of “H. aquile pullus.” But Balade XLVI's emphasis on silence, discretion, and thoughtfulness encourage greater reflection in the reader, ${ }^{66}$ too, on the broader arc of the lovers' dialogue: the abrupt revelation of amatory discord in Balade XL, its equally sudden disappearance just four poems later, and its politically charged allusions to classical and especially Trojan history. Even leaving aside the potential for disruptive

eaglet (pullus aquilae) who comes from across the sea to depose a white king (rex albus-i.e., Richard, whose badge was a white hart). Henry was supposed the eagle because the symbol of John the Evangelist, namesake of his father, John of Gaunt, was an eagle, and because the badge of Edward III, his grandfather, was an eagle also-little notice was given to Edward's status as Richard's grandfather also."

${ }^{65}$ See Ded. Bal. I.1 and II.33.

${ }^{66}$ The refrain line quoted above emphasizes silence and thoughtfulness; other verbs of protection (guarderai, 6) and discretion (m'aviserai, 13) pepper the poem. 
love triangles, ${ }^{67}$ this sequence that concludes the Balades' narrative portion scarcely performs that seamless continuity emphasized by the last line of "H. aquile pullus." Instead, the juxtaposed performance of irreconcilable extremes of emotion presses us to consider more critically what these poems might suggest or represent.

Any hope that the last poems in the sequence might resolve these contradictions quickly evaporates, for the more gnomic tone of Balades XLVII-L raises its own set of problems. Each poem's refrain makes a claim about love:

N'est pas oiceus sil qui bien amera.

En toutz errours amour se justifie.

Lors est amour d'onour la droite meire.

Amour s'acorde a nature et resoun. ${ }^{68}$

\footnotetext{
${ }^{67}$ I do not think that the Cinkante Balades encourages us to insist upon precise and stable referents for the various figures of the meta-narrative, but it is worth remembering that if as Yeager suggests the lover of Balades XLIIII-XLVI is not the same as that of Balades I-XL, then much the greatest part of the Cinkante Balades as a whole has been devoted to his predecessor in the lady's good graces; if he is one and the same, then he stands accused of vile conduct that the lady's subsequent about-face does not resolve and, indeed, in its abruptness manages to highlight.

${ }^{68}$ These are the refrains of Balades XLVII-L respectively: "He who will love well is not lazy," "In all errors love justifies itself," "Then love is the rightful mother to honor," and "Love accords itself with nature and reason."
} 
The autonomous, amoral, self-justifying love described in Balade XLVIII is antithetical both to the love of the following two poems (where love is mother of Honor and handmaid of Reason) and to the "bon amour" promised in the dedication. Yet by using the same word in each case - we cannot instantly distinguish as between caritas and cupiditas - these poems collectively recall the early marginal glosses' challenge to distinguish between celebrations of courtly as opposed to marital love. Indeed, Balade XLVIII takes the impossibility of defining love as its opening theme: "Amour est une chose merveilouse, / Dont nulls porra savoir le droit certain. ${ }^{, 69}$ The rest of this poem consists largely of oxymora, which both characterize love itself ("odible et graciouse" [17], serf and sovereign [24]) and which love in turn creates in whatever it touches: under its influence, "le riche est povere et le courtois vilein, / L'espine est molle et la rose est urtie," and so on. ${ }^{70}$ This is a radically destabilizing poem to include at this point, after Gower has so self-consciously if heavy-handedly resolved the lover's spat of Balades XL-XLV. In their exuberantly contradictory definitions of love, Balades XLVII-L codicologically perform, as a sequence, a version of the oxymora that according to Balade XLVIII constitute love's chief characteristic. In this sense that sole dissenting poem has the last word, effectively trumping the other balades' individually performed insistence upon love's socially and ethically reinforcing power.

The sequence's final poem acknowledges these contradictions and attempts simply to define them away:

\footnotetext{
${ }^{69} \mathrm{Bal}$. XLVIII.1-2: "Love is a marvelous thing / Of which no one is able to know the true certainty."

${ }^{70}$ Bal. XLVIII.5-6: "the rich man is poor and the courteous man a knave, / The thorn is soft and the rose is a nettle."
} 
Amour de soi est bon en toute guise,

Si resoun le governe et justifie;

Mais autrement, s'il naist de fole emprise,

N'est pas amour, ainz serra dit sotie. ${ }^{71}$

And so we are told, finally, that the socially disruptive contradictions of Balade XLVIII weren't love at all, but rather madness. Yet the echoes between the two balades make it hard to forget the assertion of love's disruptive qualities made by the earlier poem, which included the same "amour de soi" formula we see above (XLVIII.3) and similar language of justification in its refrain ("en toutz errours amour se justifie"). Its envoy, moreover, defined love in terms of that very sotie which this later balade insists is wholly different from it: "N'est qui d'amour poet dire la sotie."72 Balade LI's earnest protestations thus recall and draw attention to precisely the poem whose unsetttling assertions it is attempting to shut down. This gambit is comparable to others we have seen in the Cinkante Balades: the early marginal glosses' initial demand that we read for more than the poems' apparent desport, only then to insist on the fundamental difference of later poems that look very much the same; and the abrupt, forced resolution of a lovers' spat that was itself an abrupt shift from the narrator's tone to that point. This final instance of this pattern that we have just considered, however, is especially striking because its very existence, after Gower has supposedly shut the lid on troublesome kinds of love by imposing a happy ending to the lovers' quarrel, suggests the ultimate futility of all such

\footnotetext{
${ }^{71}$ Bal. LI.1-4: "Love in itself is good in every guise, / If reason governs and justifies it; / But otherwise, it is but a foolish enterprise, / It is not love, but will be called madness."

${ }^{72}$ Bal. XLVIII.23: "There is no one who is able to describe the folly of love."
} 
moves. Whatever their intention, all these moments elicit a more careful, skeptical mode of reading than either the poems' genre or the dedication's emphasis on desport might otherwise suggest.

Earlier I raised but did not answer the question of what a Henrician context might suggest about how to interpret both these discontinuities and the manuscript's efforts to resolve them. The Cinkante Balades' final stanza gives new urgency to this issue by naming Henry explicitly, and both recalling and rewriting elements of the dedication:

O gentile Engleterre, a toi j'escrits,

Pour remembrer ta joie q'est novelle,

Qe te survient du noble Roi Henri,

Par qui dieus ad redrescé ta querele:

A dieu purceo prient et cil et celle, Q’il de sa grace au fort Roi coroné Doignt peas, honour, joie et prosperité. ${ }^{73}$

The final list of virtues echoes those that open the first dedicatory balade and close the second ${ }^{74}$ the $r e-$ verbs italicized above recall the profusion of such verbs in the dedication and earlier in the manuscript; and the reference to Henry as "Roi coroné"

\footnotetext{
${ }^{73}$ Bal. LI.25-31: "Oh gentle England, I write for you, / In remembrance of your new joy, / Which comes to you from the noble King Henry, / By whom God has redressed your quarrel: / Let one and all therefore pray to God, / That He who with His grace crowned the King indeed / May give peace, honor, joy and prosperity.” Emphasis mine.

74 "Pité, prouesse, humblesse, honour roial” (Ded. Balade I.1: "Mercy, prowess, humility, regal honor"), and "Honour, valour, victoire et bon esploit, / Joie et saunté, puissance et seignurie" (Ded. Balade II.33-34: "Honor, valor, victory, and good success, / Joy and health, power and lordship").
} 
evokes the "ore avetz receu le coronal" line that we have discussed (Ded. Bal. I.17).

Gower's claim to be writing to England (a toi j'escrits) recalls the phrase with which he addressed Henry earlier (ce que je vous escris, Ded. Bal. I.22), though this echo reinforces the fact that Henry is only being referred to here, not addressed. The most striking thing about this stanza, however, is its explicit reference to discord-the querele of line 28 - that the dedication would allude to only obliquely. ${ }^{75}$ Within this stanza, the most obvious referent for such conflict would seem to be that which led to Richard II's deposition and Henry's elevation as king. But in the context of the Cinkante Balades, it seems equally likely to recall the quarrel between the lovers in Balades XL-XLIIII, and thus continues the subtle connection of the political and amatory realms that the sequence as a whole has gradually suggested.

In so doing, moreover, this querele suggests a cautious perspective on Henry's accession, for although this stanza in isolation is straightforwardly laudatory, the idea of redressed quarrels reminds readers of the fact that earlier narrative discord (between the lovers) and thematic discontinuity (on just what love really is) were more papered over than resolved. This ambivalence is thoroughly consonant with what we have seen in In Praise of Peace and "Rex celi deus," where authorial revisions suggested ambiguity at odds with those poems' outwardly celebratory tone and content. These suggestions gather force cumulatively, and any one of them might be declined, so my goal here is less to argue for a specific interpretation of the Cinkante Balades than it is to emphasize that all these poems are most compellingly complex when analyzed in the context of form and

\footnotetext{
${ }^{75}$ E.g. the references to "our former servitude" (Ded. Bal. I.6), or to beginning again the "bon amour" that used to exist in former times (Ded. Bal. II.21-24).
} 
history alike: the codicological form of the Trentham manuscript, which includes

multiple invitations to read its poems as building upon and commenting upon one another, and its intervening material (incipits, explicits, dedications) as significant; and the authorial history of Gower himself, which makes many of these invitations legible and significant in the context of a broader history of Lancastrian power.

The next work in the manuscript, the Latin poem "Ecce patet tensus," amply demonstrates the impossibility of simply defining away the dangerous, disruptive side of love as mere sotie, as the concluding Balade LI has just attempted to do. This poem, which is unique to Trentham, opens with the declaration that "love conquers all" (3), and depicts a lord Cupid whose reign is terrifyingly absolute in its destructive chaos. ${ }^{76}$ The blind god "knows not whither his trail will lead" (4), and his blindness is matched only by his power: "everyone obeys his precepts" (12), for "he is the crowned king" (13) who "subdues everything that Nature has created" (15). The description of Cupid as coronatus —emphasized by the fact that a crown is not a universal attribute for him—recalls the Cinkante Balades' initial address to Henry and concluding reference to him. ${ }^{77}$ It is hard to read this resemblance as other than admonitory, given the amatory subject matter of the

\footnotetext{
${ }^{76}$ Elliot Kendall has recently proposed that Cupid in the Confessio Amantis embodies a "magnificent lordship" that alienates and objectifies the servitor, as contrasted with the more productive "reciprocalist lordship" offered by Venus; this interpretation is consonant with my reading of Cupid in "Ecce patet tensus." See his Lordship and Literature: John Gower and the Politics of the Great Household (Oxford: Oxford University Press, 2008), 109-131.

${ }^{77}$ Cf. Ded. Bal. I.17: "ore avetz receu le coronal" ("you who have now received the crown”); Bal. LI.30: "fort Roi coroné" (“strong crowned king”), emphases mine.
} 
Cinkante Balades and the fact that several moments in "Ecce patet tensus" look even further back in the manuscript, to In Praise of Peace:

He [Cupid] wounds every nation, but receives no wound himself.

In the wars of Love there is no victor on earth,

Nor has anyone concluded with him a firm treaty of peace.

Trentham's first long poem admonished Henry to be a peacemaker, so at its most basic "Ecce patet tensus" holds up Cupid as an anti-model for the new king. But a set of four couplets apostrophizing human nature hints at the difficulty of avoiding completely the competing model of kingship that Cupid embodies:

O human nature, which no one can abolish,

Nor yet excuse the evils it does!

O human nature, irresistibly disposed

To that unlawful thing which it cannot shun!

O human nature, that contains two mixed contraries

But is not allowed to follow the deeds of both!

O human nature, which always has war within itself

Of body and soul, both seeking the same authority!

This passage emphasizes that every person must somehow cope with two antithetical and competing impulses, the "two mixed contraries" of human nature: "body and soul," each seeking to be ruler of the self. The couplets' anaphora distances this message from Henry by universalizing its relevance. But Trentham has been full of competing dualities that 
threaten to morph into one another: the Alexander/Solomon and Alexander/Henry binaries of In Praise of Peace; the Henry praised by "Rex celi deus," competing with the spectral presence of Richard from the lines' earlier existence in Vox Clamantis; and the "bon amour" to which the Cinkante Baldes exhort the king, which dissolved into charges of treachery only hastily and somewhat artificially resolved at the end of the sequence. "Ecce patet tensus" presents offers yet another: a lord who competes with Henry, and whose amor differs radically from the "bon amour" that Henry was earlier imagined promoting.

These broad structural and thematic connections between "Ecce patet tensus" and other works in Trentham are reinforced by more local echoes, too. A reference to Solomon in "Ecce patet tensus," for example, recalls his role in In Praise of Peace, where he served as an exemplary figure for Henry, the one who (unlike Alexander) "ches wisdom unto the governynge / Of goddis folk" and thereby "gat him pees" $(31-32,35)$. But as the later Latin poem would have it, even "the intelligence of Solomon" can boast of "nothing praiseworthy" when faced with the all-consuming destructiveness of Love (22). This line not only casts retrospective doubt on the exemplary status he enjoyed earlier in the manuscript, but recalls in its terms his characterization in the Confessio, where his voracious sexual appetite prompted his descent into idolatry (VII.4469-4573). But the Alexandrine model, exemplary in the Confessio and abruptly reversed in In Praise of Peace, is no more acceptable here than that of Solomon. Not just Solomon's wisdom but Samson's strength and David's sword are powerless in the face of love (21), and the image of Cupid as an indiscriminate conqueror who refuses to make peace takes the negative depiction of the conquering Alexander initiated in Trentham's first poem to 
an almost nightmarish extreme. All of this broader significance, however, is intelligible only in the context of Trentham's codicological form, and in that sense "Ecce patet tensus" offers its own form of duality: interpreted as I have suggested, it is the most cautionary of any of Trentham's texts about Henry's accession, but it also includes the fewest explicit indications—zero, in fact—-that it should be read in this way; such an interpretation depends on our willingness to see Trentham's larger codicological form as meaningful. "Ecce patet tensus" thus allows itself to be read as a conventionally homiletic text whose universally applicable admonitions neither threaten nor particularly speak to Henry; or as a serious warning to right behavior that has gained cumulative force by building upon the images and associations of the manuscript as a whole. My larger point is that by prompting us to ponder the issue, Trentham's codicological form gives its texts deeper aesthetic resonance than they have if analyzed in isolation.

Trentham's final major text, the Traitié pour essampler les amantz marietz, opens by continuing the project of distinguishing between the love-as-sotie of Balade XLVIII and "Ecce patet tensus," and a more wholesome love, restrained by the body's recognition that reason must be its constable. ${ }^{78}$ Balades I-V hail marriage as God's instrument for promoting this second, nobler love, and in that sense the "Ecce patet tensus"/Traitié pairing appears to be playing a similar role to the Confessio/Traitié

\footnotetext{
${ }^{78}$ As noted earlier, the folio that contained the end of "Ecce patet tensus" (if it is in fact incomplete) and the first balade and a half of the Traitié has been cut away. Since the textual witnesses to the Traitié are quite consistent, I have assumed for the purposes of my argument that the Traitie as it originally appeared in Trentham was essentially equivalent to the versions in Fairfax 3, Glasgow Hunterian T.2.17, and Bodley 294, our three surviving witnesses to Traitié's first balade and a half. (The All Souls manuscript also includes the Traitié, but it lacks the first two poems, and first three lines of the third.)
} 
pairing in the Fairfax manuscript that gives the poem its modern title. ${ }^{79}$ Together, these two poems finally subdivide the category of love, whose dangerous slipperiness we saw amply displayed in the Cinkante Balades, into the bad ("Ecce patet tensus") and the good (Traitié). Indeed, the Trentham copy of the Traitié appears particularly eager to avoid love's contradictions, for it omits the Latin poem "Est amor," which follows the balade sequence in all other manuscripts and consists of oxymoronic definitions of love akin to those of Balade XLVIII in the Cinkante Balades ${ }^{80}$ Read in this way, we could see the Traitie as attempting to shut down not just these definitional ambiguities but others that we have considered in Trentham: those of In Praise of Peace and "Rex celi deus," where authorial rewriting hinted at warnings for their royal addressee; or of the Cinkante Balades, whose dedication implied a larger relevance for the "bon amour" it imagined Henry promoting, but that the sequence's meta-narrative only imperfectly displayed. Indeed, the Traitié declines clear opportunities to emphasize the Henrician context that

\footnotetext{
${ }^{79}$ Oxford, Bodleian Library, MS Fairfax 3 includes the following link between Confessio Amantis and the Traitié: "Puisqu'il ad dit ci devant en Englois par voie d'essample la sotie de cellui qui par amours aime par especial, dirra ore apres en François a tout le monde en general un traitié selonc les auctour pour essampler les amantz marietz, au fin q'ils la foi de lour seintes espousailes pourront par fine loialté guarder, et al honour de dieu salvement tenir." ("Because the preceding poem in English was by way of example of the foolishness of those in particular who love in a courtly manner, now the subsequent treatise will be in French, for all the world generally, following the authorities, as an example for married lovers, in order that they might be able to protect the promise of their sacred spousal through perfect loyalty, and truly hold fast to the honor of God.”) Quoted in Yeager, John Gower: The French Balades, 34.

${ }^{80}$ For "Est Amor," see Yeager, John Gower: The Minor Latin Works, 32 f. and 67-69. Claims that love is “warlike peace" (pax bellica, 1), "a peaceful fight" (pugna quietosa, 3), and "a joyful death" (mors leta, 7) typify the poem.
} 
the manuscript's early texts established. It nowhere addresses or refers to the king, and the poem's final moves instead highlight Gower: the envoy that concludes the Traitié (the only one in the sequence) puts him in direct address with the entire world, ${ }^{81}$ while the Latin verses adjoined to the sequence's conclusion first universalize the audience of the Traitie as all who have undertaken "the sacred order of marriage," then retreat into another mention of Gower, and the fact that he himself, "old in years ... / Safely approach[es] the marriage bed in the order of husbands." 82

Yet the Traitie is still crucially informed by other poems in the manuscript, particularly in its choice of verse form and exempla. Like the Cinkante Balades, of course, it is a balade sequence. But its uniformly rime royal stanzas, as opposed to the Cinkante Balades' varied stanza structures, look back to In Praise of Peace, which aside from the letter to Venus at the end of the Confessio (VIII.2217-2300) is Gower's only use of rime royal in English. These two poems are thematically linked as well. In Praise of Peace considered how the examples of two celebrated antecedents, Alexander and Solomon, might inform the reign of the newly crowned Henry IV. The Traitié, meanwhile, uses kings for most of its exempla on the dire consequences that await adulterers: Nectanabus and Ulysses, Jason and Agamemnon, Tarquin and Albinus, Tereus and Pharaoh are all duly punished for their adulterous behavior. ${ }^{83}$ This adultery, moreover, is typically framed as violence or conquest, from Nectanabus's rape of

\footnotetext{
${ }^{81}$ Bal. XVIII.22 f.: "Al université de tout le monde / Johan Gower ceste Balade envoie. . . ."

${ }^{82}$ See Yeager, John Gower: The Minor Latin Works, 33.

${ }^{83}$ On what this might suggest about the dating and intended audience of the Traitié, see Cathy Hume, "Why Did Gower Write the Traitié?," in John Gower, Trilingual Poet: Language, Translation, and Tradition, ed. Elizabeth Dutton with John Hines and R. F. Yeager (London: D. S. Brewer, 2010), 263-75.
} 
Olimpeas (VI.4) or Hercules' conquest of Deianira (VII.5-6: "en armes conquestoit / La belle Deianire par bataile," emphasis mine), to Albinus's marriage of his defeated enemy's daughter (XI.3-45) or Pharaoh's ravine of Abraham's wife Sarrai (XIII.9). This association of love and war recalls not just the depiction of Cupid as a rapacious warlord in "Ecce patet tensus," but also the Trojan references in the Cinkante Balades and In Praise of Peace's more general admonition to avoid conquest. The emphasis on royal figures in these exempla, moreover, means that while Trentham ends by moving away from the specifically Henrician context that its initial texts suggested, it continues and even strengthens the focus on kingship more generally that we have seen in each of the main texts so far: the first three dedicated to or addressing Henry directly, the final two presenting counter-models of royal misbehavior, from Cupid's in "Ecce patet tensus" to that of legendary adulterous kings in the Traitié.

This makes the Traitié's final exemplum, the only positive one in the sequence, particularly important. Balade XVI tells of how the Roman emperor Valentinian lived to a miraculously old age by maintaining his chastity. He denied meriting any praise for "the kinges and the londes / To his subjeccion put under, ${ }^{, 84}$ however, accepting accolades only for his victory over fleshly desire. He thus not only becomes the antithesis of Cupid as presented in "Ecce patet tensus," but also presents a model of spiritual might that could redeem the negative associations of earthly conquest from In Praise of Peace. The only problem with this positive interpretation of Valentinian is that he seems curiously at odds with the Traitié's focus on marriage, since he achieved his heroic conquest of the flesh

\footnotetext{
${ }^{84}$ Confessio Amantis, V.6408 f. Gower also tells the story of Valentinian in both the Confessio (V.63956417) and Mirour de l'Omme (17089-17100).
} 
without the help of matrimony. The strangeness of this exemplum will be most apparent to readers of Trentham with a detailed knowledge of Gowerian antecedents, since Gower's other two treatments of him are more explicit about the fact that Valentinian never married. ${ }^{85}$ Even here, however, the Traitié cites him as an example of one of those few who "guarderont chaste lour condicion," $" 86$ before pivoting to assert near the end of the poem that "en mariage est la perfeccioun. ${ }^{, 87}$ The Traitié's only positively depicted figure thus turns out actually to have rejected the institution that the sequence as a whole supposedly praises. We should recognize here a gambit we have seen throughout Trentham: a piece of praise or a positive exemplum that reveals darker significance when apprehended in the context of the manuscript, and Gower's career, as a whole.

Trentham's final text, "Henrici quarti primus," puts this issue of Gower's career squarely before us; it is brief enough to quote in its entirety:

It was in the first year of the reign of King Henry IV

When my sight failed for my deeds.

All things have their time; nature applies a limit,

Which no man can break by his own power.

I can do nothing beyond what is possible, though my will has remained;

My ability to write more has not stayed.

While I was able I wrote, but now because stooped old age

\footnotetext{
${ }^{85} \mathrm{He}$ comes up in Mirrour de l'Omme in the ecnomium of virginity (16825-17136), not the subsequent discussion of matrimony (17137-17748), and in the Confessio is introduced as "withoute Mariage" (V.6401).

${ }^{86}$ Bal. XVI.4: "Guard their chaste condition."

${ }^{87}$ Bal. XVI.19: "In marriage is perfection."
} 
Has troubled my senses, I leave writing to the schools.

Let someone else more discreet who comes after me write,

For from this time forth my hand and pen will be silent.

Nevertheless I ask this one final thing, the last of my words:

That God make our kingdoms prosperous in the future. Amen. ${ }^{88}$

Two other, apparently later versions of this poem assert a simple physical causation ("I stopped writing, because I am blind," and "I am unable to write any longer, because I am blind") for the poet's farewell to writing, instead of the circumlocutions used here: "my sight failed for my deeds" (2) and "stooped old age has troubled my senses" (7 f.). ${ }^{89}$

Compared to the later two versions, which specify "writing" both at that point and almost obsessively throughout, these are curiously allusive formulations. ${ }^{90}$ And that makes

\footnotetext{
${ }^{88}$ R. F. Yeager, John Gower: The Minor Latin Works, 47.

89 "Henrici quarti primus" is unique to Trentham. A slightly longer, fifteen-line version, "Henrici regis annus," appears in the Cotton, Harley, and Glasgow manuscripts, while the All Souls manuscript version opens "Quicquid homo scribat" and consists of seventeen lines. See Yeager, John Gower: The Minor Latin Works, 47-50, for all three. The parenthetical quotations about blindness are from lines 2 and 4 of "Henrici regis annus" and "Quicquid homo scribat," respectively.

${ }^{90}$ I should acknowledge first that "Henrici quarti primus" appears to be the earliest of the three versions, since it references the first year of Henry's reign while "Henrici regis annus" mentions the second; "Quicquid homo scribat" incorporates phrases from both versions and thus appears to be the latest. This means that we can resort to the simplest explanation for the different vocabularies of blindness: that when Trentham was being compiled, Gower merely suffered from failing eyesight, and it wasn't until a year later that he actually went blind and felt compelled to describe himself as such. This is quite possible, of course, maybe even probable, but in any event does not preclude the metaphorical interpretation of the poem I suggest above.
} 
another line in the Trentham version stand out for me: Gower's desire in line 9 that "someone else more discreet who comes after me" should write in his stead, a prayer that the final All Souls version omits. What deeds has Gower failed at in Trentham that a more discreet, more prudent, wiser man will have to take up? The poem is legible in completely conventional and therefore non-threatening terms by a Lancastrian audience, but I wonder if it might also represent a private acknowledgment that the Gower compilation it rounds out is not as fully laudatory as discretion and prudence might dictate; and that the safest course, not just the one prompted by physical disability, might be to retire from writing altogether?

This is a biographically inflected reading of Trentham's final poem. The poem itself, with its insistently repeated first-person verbs and pronouns, encourages such interpretations even as the manuscript, as we saw early on, makes itself difficult to pin down historically or paleographically as precisely intended by anyone, scribe(s) or author. In my explorations of such paradoxes throughout this essay, I hope to have demonstrated that the Trentham manuscript's codicological form works together with its individual texts and their multiple evocations of Gower's authorial history to create that excess, that refusal to submit to clear messages or single meanings, which in their various ways we saw Maura Nolan, Samuel Otter, and Derek Pearsall all propose as one key component of the literary and aesthetic. Thus far I have emphasized the ways in which Trentham creates meaning through juxtaposition and accretion, but it is worth remembering in conclusion that fragmentariness is the necessary corollary of such assemblage; every collection, examined closely, reveals destabilizing fissures, evidence of its status as a constructed object that is imperfect like every other. I have suggested 
that Trentham thematizes those fissures, allowing us to see disjunctions between the most obvious, explicit content of its texts and the significance that they might have if examined in the context of other (codicological) forms and (authorial and political) histories. Much of that significance seems to me cautionary: Trentham's early texts, laudatory and Henrician, seem more ambivalent when read in the context of Gower's authorial history and the manuscript's later, darker poems; those texts' relevance to the king, however, is far from clear unless we elect to read them in the context of the manuscript as a whole. ${ }^{91}$ My larger argument about Trentham, however, is not that it conveys a specific "message," or is "about" a specific figure. It is an artfully constructed meditation on the multiple natures and implications of kingship, and the very complexity of its construction serves to acknowledge both the visceral pleasure of using aesthetic modes to grapple with such vitally important questions, and the impossibility of creating clear-cut "propositional content" as answers to them. And this is the sense in which we can understand Trentham's literal, physical fragmentariness, alluded to briefly at the beginning of this essay, as complementing key elements of its texts' meanings even as it occludes others. Any of the manuscript's missing pieces - the fragmentary stanzas of the second

\footnotetext{
${ }^{91}$ Although I have used forms and histories both medieval and modern to argue for such a reading, it is worth acknowledging in conclusion the inescapability of idiosyncratic, personal response inherent to any such "election to read." Academia's continuing affinity for the deconstructive, and especially for imagining that artists and writers ought properly to be skeptical of political establishments, must inflect to some degree my arguments here, as must the ongoing attempts (justified, I believe) by many scholars to suggest that Gower was in fact a less blindly slavish Lancastrian than an earlier generation of critics tended to suppose. To acknowledge thus much, however, is I believe not to undermine the arguments I have made but rather more fully to historicize them.
} 
dedicatory balade and first poem of the Cinkante Balades proper, the end (perhaps) of the (perhaps) incomplete "Ecce patet tensus," and whatever linking material might once have joined it to the Traitié - might have provided the key to a certain kind of understanding of the manuscript that we now will never have. But the tidy meaning such a key might have made available to us might in turn have compromised the manuscript's aesthetic excess, by pinning down the range of shifting meanings offered by Trentham's texts and form, meaning and excess that it has been my pleasure to explore in this essay. Trentham's physical lacunae are as much a part of its texts' meaning as are its many attempts to stitch those texts together into a coherent and unified whole. The manuscript thus becomes much more than a gift to Henry IV, or a warning to him, or a book of poems about kingship, or a collection of Gower's verse. It is a reminder of why we grapple with literary texts in the first place: the fact that their delights and their frustrations, their significances and their silences, are all-literally-bound up together. ${ }^{92}$

\footnotetext{
${ }^{92}$ I am grateful to Noel Jackson, Eleanor Johnson, Steve Justice, Anne Middleton, and Bob Yeager for their consistent support and helpful comments; to the participants of the "French of England" conference held at Fordham University in the spring of 2007, where I presented preliminary thoughts on the Trentham manuscript; and to members of the 2009 MIT Women's and Gender Studies symposium where I shared thoughts on the Cinkante Balades. The two anonymous readers for $S A C$ also offered generous and insightful suggestions from which this essay has greatly benefited.
} 